\title{
Management of pineal region tumours in children
}

\author{
George A Alexiou, Maria Varela, Neofytos Prodromou \\ Department of Neurosurgery, Children's Hospital "Agia Sofia", Athens, Greece \\ Correspondence: George Alexiou. Address: Department of Neurosurgery, Children's Hospital "Agia Sofia", Athens, \\ Greece. Telephone: 30-210-652-6507. Fax: 30-210-746-7014. E-mail: alexiougrg@yahoo.gr
}

Received: November 1, 2011

Accepted: February 15, $2012 \quad$ Published: April 1, 2012

DOI : $10.5430 /$ jst.v2n2p15

URL: http://dx.doi.org/10.5430/jst.v2n2p15

\section{Abstract}

Pineal region tumors in children are rare. A wide diversity of lesion arises from the pineal gland or the surrounding tissues. Among them, germinomas, nongerminomatous germ cell tumors and pineoblastoma are the most common. These tumors do not have pathognomonic imaging findings. However, tumor markers evaluation may narrow the differential diagnosis. Symptoms are usually related to tumor size and location. Treatment depends on tumor type but still the standard management remains unclear.

\section{Key words}

Pineal tumor, children, Germinoma, Nongerminomatous germ cell tumors, Pineocytoma, Pineoblastoma, Surgery, Chemotherapy, Radiotherapy

\section{Introduction}

The pineal region is comprised of the pineal gland, posterior third ventricle, tela choroidea and velum interpositum. A wide diversity of lesion arises from the pineal gland or the surrounding tissues. The primary pineal tumors are pineoblastoma and pineocytoma. Extrapineal tumors are usually germ cell tumors, tumors of glial cell origin, meningiomas, metastases, pineal cysts or vascular malformations ${ }^{[1,2]}$.

Symptomatology of the pineal region tumors is directly related to the surrounding structures and tumor histology. Hydrocephalus is a common manifestation as a result of obstruction of the cerebrospinal fluid (CSF) pathway at the level of the aqueduct of Sylvius. Consequently, patients may present with symptom and signs of hydrocephalus. Additionally, compression of efferent pathways or the cerebellar peduncles can produce gait abnormalities. It is also not uncommon for pineal region tumors to produce endocrinological deficits ${ }^{[1]}$. Furthermore, initial clinical manifestations, are frequently ocular in nature. One of the most common symptoms (50\%-70\% of patients suffering from pineal region tumors) is Parinaud's syndrome which is characterized by typical ocular movement disorder including paralysis of upward gaze, convergence or retraction nystagmus and light-near dissociation ${ }^{[3,4]}$.

MRI has a pivotal role in the detection of pineal region tumors. However, an accurate diagnosis, other than pineal cysts, is difficult, since the majority of tumors share similar radiological findings. Germ cell tumors, non-germ cell tumors and astrocytomas usually are hypo or isointense on T1, hyperintense on T2-weighted MRI and enhance after contrast administration. CT might be useful for determining the extent of calcification ${ }^{[5]}$. Alternatively, biochemical markers in 
serum or CSF may be very helpful in establishing the final diagnosis. A-fetoprotein (AFP) and $\beta$-human chorionic gonadotropin $(\beta-\mathrm{HCG})$ are the most important. In germinomas, AFP is negative ${ }^{[6]}$. In nongerminomatous germ cell tumors AFP and $\beta-\mathrm{HCG}$ are usually elevated in serum and CSF. $\beta$-HCG is elevated in choriocarcinoma and some mixed germ cell tumors. AFP is markedly elevated in endodermal sinus tumors and elevated to a lesser degree in embryonal cell carcinomas. Usually teratomas do not secrete AFP, whereas the less differentiated immature teratomas can produce detectable amounts ${ }^{[3,6,7]}$. When both AFP and $\beta$-HCG are elevated, neuro-oncologists and neurosurgeons tend to advocate an open biopsy to distinguish malignant teratomas from undifferentiated germ cell tumors. These markers are dependable parameters for following response to therapy and failure of markers to normalize demonstrate incomplete response to therapy. Patients with elevated tumor markers appear to have a poorer survival (60\% vs. $78 \%, 5$ year overall survival) independent to tumor histology. Patients with elevated markers have a higher risk of death than those with normal markers. Patients with elevated AFP are associated with an even worse prognosis than patients with elevated $\beta-\mathrm{HCG}^{[8]}$. In the current study we reviewed the available treatment modalities for pineal region tumors in children.

\section{Surgery}

Patients with pineal tumors will develop hydrocephalus in about $90 \%$ of cases and they will require CSF diversion. Ventriculo-peritoneal (V-P) shunt placement is a viable option with low morbidity and mortality rate. However, shunt malfunction in this population is as high as $20 \%{ }^{[9,10]}$. In addition, tumor metastasis through a CSF shunt has been reported ${ }^{[11]}$. Endoscopic third ventriculostomy $(E T V C)$ is an alternative option, which also permits a biopsy of the tumor in the same procedure. Ahn et al reported that biopsy samples, obtained in the lateral ventricle or pineal region, were more favorable toward a successful diagnosis than those in the thalamus or tectal region ${ }^{[12]}$. Neuroendoscopic biopsy procedures have been proven safe with low complication rate. In a recent multicenter study neuroendoscopy provided a diagnosis in $90 \%$ of patients ${ }^{[13]}$. Furthermore, endoscopic-assisted open tumor surgery shows promise ${ }^{[14]}$. In all cases, CSF samples for the assessment of AFP and bHCG levels can be obtained during ventricle puncture and are important for tumor characterization. Stereotactic biopsy has also been used for diagnosis. Nevertheless, stereotactic biopsy has several risks since pineal region has numerous large vessels that can also be displaced from their normal position in case of tumor ${ }^{[15-18]}$. Apart from that, certain tumors such as pineoblastomas or choriocarcinomas are highly vascular, whereas histological heterogenic tumors such as mixed malignant tumors may pose a problem for an accurate diagnosis ${ }^{[19]}$. In experienced centers, stereotactic biopsy has been reported to be safe with no mortality and permanent morbidity and only $6 \%$ transient morbidity rates. Tissue diagnosis accuracy has been reported to be as high as $99 \%{ }^{[20]}$.

Benign pineal tumors can be cured with surgery alone. Nevertheless, malignant tumors, apart from aggressive resection, should be treated with radiotherapy and chemotherapy. Surgical approach to the pineal region constitutes a challenge given the complexity and the nearby several neurovascular structures. The venous anatomy is one of the most complex in the central nervous system. The main venous structures exposed during surgery are the vein of Galen with its tributaries

${ }^{[21]}$. Preservation of these deep veins is mandatory and frequently pose a limitation for the radical removal of the tumors in the pineal region ${ }^{[22]}$. The main goal of open surgery on pineal region lesions is the complete tumor removal with minimal morbidity, whenever possible. However, even if gross total excision cannot be achieved, establishment of an accurate diagnosis, maximal cytoreduction and restoration of CSF pathways may be achieved ${ }^{[23]}$.

The latest CT and MRI-based neuronavigation systems allow a more targeted approach, providing a more accurate intraoperative guidance. Thus, reduction of surgery duration and of the mortality and morbidity rates have been achieved. Furthermore, neuronavigation systems provide a better representation of the spatial relationship between cerebral veins and surrounding structures and allow for the identification of variants that will be encountered on the trajectory to reach the lesion ${ }^{[24]}$. 
Because of the central location of the pineal region in the cranial cavity, the surgical approach depends on tumor's size and extension, the tumor's relationship to the deep venous system and the splenium of the corpus callosum ${ }^{[25]}$. Among the various operative approaches, the major are:

1) The infratentorial supracerebellar approach can be used for medium or small sized tumors and when the main bulk of tumor is located below the tentorium ${ }^{[26]}$. This approach has been considered safe and effective since the midline trajectory of the approach avoids damage to the deep venous structures. However, if the lesion extends lateral or involves the corpus callosum then another approach may be required ${ }^{[27]}$. The median or paramedian suboccipital infratentorial supracerebellar approach may also be used. The later provides better visualization and preserves the deep venous system ${ }^{[22]}$.

2) The occipital transtentorial approach is usually indicated when the tumor is growing through the tentorial hiatus with a supracerebellar-infratentorial extension and the majority of the tumor is located above the tentorium ${ }^{[22,26]}$. Konovalov et al reported that this approach proved effective and safe ${ }^{[28]}$.

3) The posterior transcallosal approach is used for tumors that are located superior to the venous complex and expand anteriorly into the third ventricle, as well as for those tumors extending upward into the corpus callosum ${ }^{[29]}$.

4) The transventricular approach is used only rarely for very large eccentric lesions that extent into the lateral ventricle $^{[30,31]}$.

\section{Treatment}

\section{Pineocytoma}

Pineocytomas are exceedingly rare. Gross total resection is the most appropriate treatment and should be attempted whenever possible. Clark et al. after performing a systematic review of the literature reported that the 1 and 5 year progression free survival (PFS) rates for patients that underwent resection versus the biopsy group were $97 \%$ and $90 \%$, and $89 \%$ and $75 \%$ respectively. The 1 and 5 year PFS rates for the gross total resection group versus the group undergoing subtotal resection combined with radiation therapy were $100 \%$ and $94 \%$, and $100 \%$ and $84 \%$ respectively. The authors concluded that gross total resection should be the goal of treatment ${ }^{[32]}$. Radiotherapy administration to subtotally resected tumor is not associated with an increase in either tumor control or survival ${ }^{[33]}$. Stereotactically guided iodine-125 seed implantation has been proposed as a potential alternative to microsurgery in de novo diagnosed pineocytomas, since it was proven efficient and safe ${ }^{[34]}$.

\section{Pineoblastoma}

Pineoblastoma together with germ cell tumors are the most common pineal tumors in children. Pineoblastoma has an unpredictable clinical behavior and is usually aggressive, displaying rapid recurrence and cerebrospinal dissemination. Gross total resection has been associated with improved survival, similar to treatment with craniospinal irradiation and multi-agent chemotherapy ${ }^{[35]}$. Children under the age of 36 months with this malignant tumor, should be treated with multi-agent chemotherapy for 12 to 24 months with the goal of delaying radiation past the age of 36 months. Craniospinal irradiation before this age of 3 has been associated with significant cognitive and neuroendocrine sequelae. Tate et al. summarized the existing literature on patients with pineoblastoma and found that children under 5 years of age and subtotal tumor resection markedly worsened patient survival ${ }^{[36]}$. According to Children's Oncology Group trials, these tumors require craniospinal irradiation (with local tumor doses of at least $50 \mathrm{~Gy}$ ) and adjuvant chemotherapy ${ }^{[37]}$. When carboplatin and vincristine were administered during craniospinal irradiation followed by 6 months of non-intensive 
non-cisplatin containing adjuvant chemotherapy, an 84\% 2-years progression free survival was reported in pineoblastomas without evidence of dissemination at presentation ${ }^{[38]}$.

\section{Germ cell tumors}

\section{Germinoma}

Germinomas are the most common type of the primary CNS germ cell tumors and have a superior prognosis. They are usually solitary and located predominately in the pineal region followed by suprasellar region and basal ganglia ${ }^{[39]}$. Multifocal or disseminated lesions are associated with poorer prognosis. Germinomas usually have a predilection to spread along ventricles, supra and intrasellar areas and CSF pathways. These tumors are highly radiosensitive and historically they were treated by radiotherapy alone ${ }^{[40]}$. In children, there is an attempt to reduce the toxicity of radiation therapy by using chemotherapy in combination with reduced dose radiation to decrease the volume of normal tissue irradiated by stereotactic radiotherapy/radiosurgery ${ }^{[41]}$. Tseng et al. treated 16 children with cisplatin-based and etoposide-based chemotherapy, and $2340 \mathrm{cGy}$ of radiotherapy and reported a favorable outcome ${ }^{[42]}$. In this study, there was no treatment failure during a median follow-up period of 45 months. There was complete response to chemotherapy, monitored by brain MRI, when the initial tumor size was smaller or equal to $2.5 \mathrm{~cm}$. The authors concluded that the lower radiation dose in the combined treatment modality may reduce the neuropsychiological deficits in these children ${ }^{[42]}$.

The value of chemotherapy alone has also been investigated. However, progression-free survival was shorter in patients treated with chemotherapy alone ${ }^{[43]}$. In multifocal and disseminated disease, whole ventricle and whole central nervous system irradiation appearsedto be sufficient ${ }^{[44]}$. Germinomas usually present with negative tumor markers. The prognosis of patients with $\beta$ HCG secreting germinoma has been suggested to be worse than that of patients with pure germinoma ${ }^{[45]}$. However, a recent study found that $\beta$ HCG elevations in biopsy proven germinomas did not alter the patient's prognosis ${ }^{[46]}$.

\section{Nongerminomatous germ cell tumors}

Nongerminomatous germ cell tumors (NGGCTs) include embryonal carcinoma, choriocarcinoma, teratoma (mature, immature or with malignant transformation), yolk sac tumors and mixed germ cell tumors. NGGCTs constitute approximately $30 \%$ of the germ cell tumors and have a poor prognosis compared to germinomas. These tumors are also less radiosensitive than germinomas. Resection has been associated with favorable results ${ }^{[47-49]}$. However, attempt for gross total resection might be associated with high morbidity ${ }^{[50]}$. Furthermore, apart from mature teratoma, in which total resection is often curative; the importance of radical resection in the remaining tumors is unclear ${ }^{[51]}$. Chemotherapy has also been proven useful, resulting in complete response in one third of patients; whereas salvage therapy with irradiation is a feasible option in recurrent disease ${ }^{[52]}$. Patients with NGGCTs, in whom the lesions on MR imaging disappeared after combination therapies consisting of resection, radiation therapy, and chemotherapy, had favorable prognosis ${ }^{[43]}$. Recently, Nakamura et al reported that neoadjuvant therapy consisting of combined chemotherapy and radiotherapy followed by complete resection of the residual tumor resulted in $93 \%$ survival rate ${ }^{[53]}$.

\section{Gliomas}

Gliomas located in the pineal region are rare. They can either arise from astrocytes in the pineal gland or more commonly they grow into the pineal region arising from adjacent brain parenchyma of the quadrigeminal plate and posterior third ventricle. Low grade and high grade tumors have been reported ${ }^{[53-55]}$. In a series of 150 pediatric patients that were treated surgically for pineal region tumors, there were 14 astrocytomas and 3 glioblastomas ${ }^{[56]}$. Glioblastomas in this location are associated with high rate of leptomeningeal and ependymal metastatic disease ${ }^{[57]}$. The role of aggressive surgical resection in the management of pineal glioblastomas is not clear. After surgical excision, radiotherapy and chemotherapy survival usually does not exceed one year ${ }^{[57,58]}$. Two patients who underwent a surgical resection only died 2 months after the diagnosis ${ }^{[59,60]}$. 


\section{Meningiomas}

Meningiomas in children are rare and constitute $2.2 \%$ of all brain tumors ${ }^{[61]}$. Meningiomas in the pineal region are exceedingly rare, constituting nearly $0.3 \%$ of all intracranial meningiomas ${ }^{[62]}$. These tumors originate from velum interpositum, the double layer of pia mater that forms the roof of the third ventricle ${ }^{[63]}$. Complete resection has been associated with good results ${ }^{[64]}$. All subtypes of meningiomas have been reported in this position ${ }^{[62-64]}$.

\section{Metastases}

Metastatic tumors in the pineal region in pediatric population are exceedingly rare. In adults, Lassman et al. reported ten cases, in which the primary cancer was clinically silent ${ }^{[65]}$. The most common site of origin is the lung, followed by the breast, and other organs ${ }^{[66]}$. Surgical excision is a viable treatment option. Stereotactic radiosurgery has also been employed with good results.

\section{Pineal cysts}

Pineal cysts are of benign nature. Al-Holou et al. after evaluating 106 patients reported that 98/106 remained unchanged after a 3-year mean follow-up period. Younger age was associated with cyst change or growth on follow-up imaging. The gender, initial cyst's size and MR imaging characteristics were not significant predictors of growth or change in imaging appearance at follow-up ${ }^{[67]}$.

\section{Conclusion}

Pineal region tumors in children are rare. A wide diversity of lesions arise from the pineal gland or the surrounding tissues. Among them, germinomas, NGGCTs and pineoblastoma are the most common. These tumors do not have pathognomonic imaging findings. However, tumor marker evaluation may narrow the differential diagnosis. Symptoms are usually related to tumor size and location. Treatment depends on tumor type but still the standard management remains unclear.

\section{References}

[1] Gaillard F, Jones J. Masses of the pineal region: clinical presentation and radiographic features. Postgrad Med J. $2010 ; 86: 597-607$. PMid:20971711 http://dx.doi.org/10.1136/pgmj.2009.087460

[2] De Girolami U, Fèvre-Montange M, Seilhean D, Jouvet A. Pathology of tumors of the pineal region. Rev Neurol (Paris). 2008;164:882-95. PMid:18808766 http://dx.doi.org/10.1016/j.neurol.2008.01.008

[3] Dhall G, Khatua S, Finlay JL. Pineal region tumors in children. Curr Opin Eurol. 2010;23:576-82.

[4] Cristian Matula (2005): Tumors of the Pineal Region. In Setti S. Rengachary and Richard G. Ellenbogen: Principles of Neurosurgery pp501-520, Elsevier Mosby.

[5] Reis F, Faria AV, Zanardi VA, Menezes JR, Cendes F, Queiroz LS. Neuroimaging in pineal tumors. J Neuroimaging. 2006;16:52-58. PMid:16483277 http://dx.doi.org/10.1177/1051228405001514

[6] Kyritsis AP. Management of primary intracranial germ cell tumors. J Neuro Oncol. 2010;96:143-49. PMid:19588227 http://dx.doi.org/10.1007/s11060-009-9951-z

[7] Andrew T. Parsa, David W. Pincus, Neil A. Feldstein, Casilda M. Balmaceda, Michael R. Fetell, and Jeffrey N. Bruce: Pineal Region Tumors Ch.22 pp308-25. Tumors of the Pediatric Central Nervous System: by: Robert F. Keating, James Tait Goodrich and Roger J. Packer: 2001 Thieme.

[8] Kim A, Ji L, Balmaceda C, Diez B, Kellie SJ, Dunkel IJ, Gardner SL, et al. The prognostic value of tumor markers in newly diagnosed patients with primary central nervous system germ cell tumors. Pediatr Blood Cancer. 2008;51:768-73. http://dx.doi.org/10.1002/pbc.21741

[9] Alexiou GA, Varela M, Sfakianos G, Prodromou N. Shunting for the treatment of arachnoid cysts in children. Neurosurgery. 2010;67:1632-36; PMid:21107193 http://dx.doi.org/10.1227/NEU.0b013e3181f94476

[10] Yamini B, Refai D, Rubin CM, Frim DM. Initial endoscopic management of pineal region tumors and associated hydrocephalus: Clinical series and literature review. J Neuro Surg. 2004;100(5 Suppl Pediatrics):437-41. 
[11] Ingold B, Moschopulos M, Hutter G, Seeger H, Röthlisberger B, Landolt H, et al. Abdominal seeding of an atypical teratoid/rhabdoid tumor of the pineal gland along a ventriculoperitoneal shunt catheter. Acta Neuropathol. 2006;111:56-59. PMid:16328512 http://dx.doi.org/10.1007/s00401-005-1112-7

[12] Ahn ES, Goumnerova L. Endoscopic biopsy of brain tumors in children: Diagnostic success and utility in guiding treatment strategies. J Neurosurg Pediatr. 2010;5:255-62. PMid:20192642 http://dx.doi.org/10.3171/2009.10. PEDS09172

[13] Oppido PA, Fiorindi A, Benvenuti L, Cattani F, Cipri S, Gangemi M, et al. Neuroendoscopic biopsy of ventricular tumors: A multicentric experience. Neurosurg Focus. 2011;30:E2. PMid:21456929 http://dx.doi.org/10.3171/2011.1.FOCUS10326

[14] Wong TT, Chen HH, Liang ML, Yen YS, Chang FC. Neuroendoscopy in the management of pineal tumors. Childs Nerv Syst. 2011;27:949-59. PMid:21344242 http://dx.doi.org/10.1007/s00381-010-1325-5

[15] Field M, Witham TF, Flickinger JC, Kondziolka D, Lunsford LD. Comprehensive assessment of hemorrhage risks and outcomes after stereotactic brain biopsy. J Neurosurg. 2001;94:545-51. PMid:11302651 http://dx.doi.org/10.3171/jns.2001.94.4.0545

[16] Regis J, Bouillot P, Rouby-Volot F, Figarella-Branger D, Dufour H, Peragut JC. Pineal region tumors and the role of stereotactic biopsy: review of the mortality, morbidity, and diagnostic rates in 370 cases. Neurosurgery. 1996;39:907-12. PMid:8905744 http://dx.doi.org/10.1227/00006123-199611000-00003

[17] Peragut JC, Dupard T, Graziani N, Sedan R. Prevention of risk in stereotaxic biopsy of various tumors of the pineal region. Apropos of 3 cases. Neurochirurgie 1987;33:23-27 PMid:3550503

[18] Kreth FW, Schätz CR, Pagenstecher A, Faist M, Volk B, Ostertag CB. Stereotactic management of lesions of the pineal region. Neurosurgery. 1996;39:280-89. PMid:8832665 http://dx.doi.org/10.1097/00006123-199608000-00010

[19] Chandrasoma PT, Smith MM, Apuzzo MLJ. Stereotactic biopsy in the diagnosis of brain masses: Comparison of results of biopsy and resected surgical specimen. Neurosurgery 1989;24:160-65. PMid:2537475 http://dx.doi.org/10.1227/00006123-198902000-00002

[20] Lefranc M, Touzet G, Caron S, Maurage CA, Assaker R, Blond S. Are stereotactic sample biopsies still of value in the modern management of pineal region tumours? Lessons from a single-department, retrospective series. Acta Neurochir (Wien). 2011;153:1111-21 PMid:21331478 http://dx.doi.org/10.1007/s00701-010-0936-7

[21] Chaynes P. Microsurgical anatomy of the great cerebral vein of Galen and its tributaries. J Neurosurg 2003;99:1028-38 PMid:14705731 http://dx.doi.org/10.3171/jns.2003.99.6.1028

[22] Juha Hernesniemi, Rossana Romani, Baki S. Albayarak, Hanna Lehto, Reza Dashti, Christian Ramsey, Ayse et al. Microsurgical management of pineal region lesions: Personal Experience with 119 patients. Surgical Neurology 2008;70:576-83. PMid:19055952 http://dx.doi.org/10.1016/j.surneu.2008.07.019

[23] Mario Giordano, Karsten H.Wrede, Lennart H. Stieglitz, Madjid Samii, Wolf O. Ludemann. Identification of venous variants in the pineal region with 3D preoperative Computed tomography and magnetic resonance imaging navigation. A statistical study of venous anatomy in living patients. J Neurosurg 106:1006-11. PMid:17564172 http://dx.doi.org/10.3171/jns.2007.106.6.1006

[24] Mario Ammirati, Antonio Bernardo, Angelo Musumeci, Albino Bricolo. Comparison of different infratentorial-supra- cerebellar approaches to the posterior and middle incisural space: A candaveric study. J Neurosurg. 2002;97:922-28. PMid:12405382 http://dx.doi.org/10.3171/jns.2002.97.4.0922

[25] Kennedy BC, Bruce JN. Surgical approaches to the pineal region. Neurosurg Clin N Am. 2011;22:367-80. PMid:21801985 http://dx.doi.org/10.1016/j.nec.2011.05.007

[26] Michael S.B. Edwards, M.D. and James E. Baumgartner, M.D. (1994): Pineal region tumors. In William R. Cheek, M.D., Arthur E. Marlin, M.D., David G. McLone, M.D. PhD, Donald H. Reigel, M.D., Marion L. Walker, M.D.: Pediatric Neurosurgery. Surgery of the Developing Nervous System. American Society of Pediatric Neurosurgeons Section of Pediatric Neurosurgery of the American Association of Neurological surgeons 3rd Edition pp429-36 Saunders.

[27] Behari S, Jaiswal S, Nair P, Garg P, Jaiswal AK. Tumors of the posterior third ventricular region in pediatric patients: The Indian perspective and a review of literature. J Pediatr Neurosci. 2011;6(Suppl 1):S56-71. PMid:22069432 http://dx.doi.org/10.4103/1817-1745.85713

[28] Konovalov AN, Pitskhelauri DI. Principles of treatment of the pineal region tumors. Surg Neurol. 2003;59:250-68. http://dx.doi.org/10.1016/S0090-3019(03)00080-6

[29] Keijii Sano (1993): Pineal Region Masses. General Considerations. In Michael L. J. Apuzzo, M.D., Brain Surgery: Complication Avoidance and Management Vol.1 pp463-73 .Churchill Livingston

[30] Jeffrey N. Bruce: Pineal Tumors. In Youmans Neurological Surgery 5th Edition Vol.1pp1011-1029. SAUNDERS

[31] Herrmann HD, Winkler D, Westphal M. Treatment of tumors of the pineal region and posterior part of the third ventricle. Acta Neurochir (Wien). 1992;116:137-46. PMid:1502947 http://dx.doi.org/10.1007/BF01540866

[32] Clark AJ, Ivan ME, Sughrue ME, Yang I, Aranda D, Han SJ, et al. Tumor control after surgery and radiotherapy for pineocytoma. J Neurosurg. 2010;113:319-24. PMid:20136388 http://dx.doi.org/10.3171/2009.12.JNS091683 
[33] Clark AJ, Sughrue ME, Aranda D, Parsa AT. Contemporary management of pineocytoma. Neurosurg Clin N Am. 2011;22:403-7. PMid:21801989 http://dx.doi.org/10.1016/j.nec.2011.05.004

[34] Maarouf M, El Majdoub F, Bührle C, Voges J, Lehrke R, Kocher M, et al. Pineal parenchymal tumors. Management with interstitial iodine-125 radiosurgery. Strahlenther Onkol. 2010;186:127-34. PMid:20339824 http://dx.doi.org/10.1007/s00066-010-2096-3

[35] Gilheeney SW, Saad A, Chi S, Turner C, Ullrich NJ, Goumnerova L, et al. Outcome of pediatric pineoblastoma after surgery, radiation and chemotherapy. J Neurooncol. 2008;89:89-95. PMid:18415046 http://dx.doi.org/10.1007/s11060-008-9589-2

[36] Tate M, Sughrue ME, Rutkowski MJ, Kane AJ, Aranda D, McClinton L, et al. The long-term postsurgical prognosis of patients with pineoblastoma. Cancer. 2011 Jun 29. doi: 10.1002/cncr.26300. PMid:21717450 http://dx.doi.org/10.1002/cncr.26300

[37] Kretschmar C, Kleinberg L, Greenberg M, Burger P, Holmes E, Wharam M. Pre-radiation chemotherapy with response-based radiation therapy in children with central nervous system germ cell tumors: A report from the Children's Oncology Group. Pediatr Blood Cancer. 2007;48:285-91. http://dx.doi.org/10.1002/pbc.20815

[38] Jakacki R, Zhou T et al. Outcome of patients with pineoblastoma treated with carboplatin as radiosensitizer during radiotherapy followed by adjuvant cyclophosphamide and vincristine: Preliminary results of CCG 99701. Neuro Oncol. 2007;9:200.

[39] Wang Y, Zou L, Gao B. Intracranial germinoma: Clinical and MRI findings in 56 patients. Childs Nerv Syst. 2010;26:1773-77. PMid:20665036 http://dx.doi.org/10.1007/s00381-010-1247-2

[40] Jean-Louis Habrand, Renaud De Crevoisier. Radiation therapy in the management of childhood brain tumors. Child's Nerv Syst 2001;3:121-33 PMid:11305764 http://dx.doi.org/10.1007/s003810000365

[41] Zissiadis Y, Dutton S, Kieran M, Goumnerova L, Scott RM, Kooy HM, et al. Stereotactic radiotherapy for pediatric intracranial germ cell tumors. Int J Radiat Oncol Biol Phys. 2001;51:108-12. http://dx.doi.org/10.1016/S0360-3016(01)01569-3

[42] Tseng CK, Tsang NM, Jaing TH, Liau CT, Wu CT, Lin KL. Outcome of central nervous system germinoma treatment by chemoradiation. J Pediatr Hematol Oncol. 2011;33:e138-42. PMid:21516012 http://dx.doi.org/10.1097/MPH.0b013e31820d0c69

[43] Kanamori M, Kumabe T, Saito R, Yamashita Y, Sonoda Y, Ariga H, et al. Optimal treatment strategy for intracranial germ cell tumors: a single institution analysis. J Neurosurg Pediatr. 2009;4:506-14. PMid:19951035 http://dx.doi.org/10.3171/2009.7.PEDS08288

[44] Kawabata Y, Takahashi JA, Arakawa Y, Shirahata M, Hashimoto N. Long term outcomes in patients with intracranial germinomas: A single institution experience of irradiation with or without chemotherapy. J Neuro Oncol. 2008;88:161-67. PMid:18286232 http://dx.doi.org/10.1007/s11060-008-9542-4

[45] Aoyama H, Shirato H, Ikeda J, Fujieda K, Miyasaka K, Sawamura Y. Induction chemotherapy followed by low-dose involved-field radiotherapy for intracranial germ cell tumors. J Clin Oncol. 2002;20:857-65. PMid:11821471 http://dx.doi.org/10.1200/JCO.20.3.857

[46] Kim A, Ji L, Balmaceda C, Diez B, Kellie SJ, Dunkel IJ, Gardner SL, et al. The prognostic value of tumor markers in newly diagnosed patients with primary central nervous system germ cell tumors. Pediatr Blood Cancer. 2008;51:768-73. http://dx.doi.org/10.1002/pbc.21741

[47] Matsutani M, Sano K, Takakura K, Fujimaki T, Nakamura O, Funata N, Seto T. Primary intracranial germ cell tumors: A clinical analysis of 153 histologically verified cases. J Neurosurg. 1997;86:446-55. PMid:9046301 http://dx.doi.org/10.3171/jns.1997.86.3.0446

[48] Shinoda J, Sakai N, Yano H, Hattori T, Ohkuma A, Sakaguchi H. Prognostic factors and therapeutic problems of primary intracranial choriocarcinoma/germ-cell tumors with high levels of HCG. J Neurooncol. 2004;66:225-40. PMid:15015791 http://dx.doi.org/10.1023/B:NEON.0000013499.74404.81

[49] Ogawa K, Toita T, Nakamura K, Uno T, Onishi H, Itami J, Shikama N, Saeki N, Yoshii Y, Murayama S. Treatment and prognosis of patients with intracranial nongerminomatous malignant germ cell tumors: A multiinstitutional retrospective analysis of 41 patients. Cancer. 2003;98:369-76. PMid:12872359 http://dx.doi.org/10.1002/cncr.11495

[50] Schild SE, Haddock MG, Scheithauer BW, Marks LB, Norman MG, Burger PC, Wong WW, Lyons MK, Schomberg PJ. Nongerminomatous germ cell tumors of the brain. Int J Radiat Oncol Biol Phys. 1996;36:557-63. http://dx.doi.org/10.1016/S0360-3016(96)00354-9

[51] Noudel R, Vinchon M, Dhellemmes P, Litré CF, Rousseaux P. Intracranial teratomas in children: the role and timing of surgical removal. J Neurosurg Pediatr. 2008;2:331-38. PMid:18976103 http://dx.doi.org/10.3171/PED.2008.2.11.331

[52] Kellie SJ, Boyce H, Dunkel IJ, Diez B, Rosenblum M, Brualdi L, et al. Primary chemotherapy for intracranial nongerminomatous germ cell tumors: results of the second international CNS germ cell study group protocol. J Clin Oncol. 2004;22:846-53. PMid:14990640 http://dx.doi.org/10.1200/JCO.2004.07.006

[53] Nakamura H, Makino K, Kochi M, Ushio Y, Kuratsu J. Evaluation of neoadjuvant therapy in patients with nongerminomatous malignant germ cell tumors. J Neurosurg Pediatr. 2011;7:431-38. PMid:21456918 http://dx.doi.org/10.3171/2011.1.PEDS10433 
[54] Barnett DW, Olson JJ, Thomas WG, Hunter SB. Low-grade astrocytomas arising from the pineal gland. Surg Neurol. 1995;43:70-75. http://dx.doi.org/10.1016/0090-3019(95)80043-G

[55] Hirato J, Nakazato Y. Pathology of pineal region tumors. J Neuro-Oncol. 2001;54:239-49. PMid:11767290 http://dx.doi.org/10.1023/A:1012721723387

[56] Jia W, Ma Z, Liu IY, Zhang Y, Jia G, Wan W. Transcallosal interforniceal approach to pineal region tumors in 150 children. J Neurosurg Pediatr. 2011;7:98-103. PMid:21194293 http://dx.doi.org/10.3171/2010.10.PEDS0976

[57] Amini A, Schmidt RH, Salzman KL, Chin SS, Couldwell WT. Glioblastoma multiforme of the pineal region. J Neurooncol. 2006;79:307-14. PMid:16645719 http://dx.doi.org/10.1007/s11060-006-9145-x

[58] Toyooka T, Miyazawa T, Fukui S, Otani N, Nawashiro H, Shima K. Central neurogenic hyperventilation in a conscious man with CSF dissemination from a pineal glioblastoma. J Clin Neurosci. 2005;12:834-37. PMid:16198924 http://dx.doi.org/10.1016/j.jocn.2004.09.027

[59] Gasparetto EL, Warszawiak D, Adam GP, Bleggi-Torres LF, de Carvalho Neto A. Glioblastoma multiforme of the pineal region: Case report. Arq Neuropsiquiatr. 2003;61:468-72. PMid:12894287 http://dx.doi.org/10.1590/S0004-282X2003000300027

[60] Moon KS, Jung S, Jung TY, Kim IY, Lee MC, Lee KH. Primary glioblastoma in the pineal region: A case report and review of the literature. J Med Case Reports. 2008;2:288. PMid:18752674 http://dx.doi.org/10.1186/1752-1947-2-288

[61] Alexiou GA, Mpairamidis E, Psarros A, Sfakianos G, Prodromou N. Intracranial meningiomas in children: Report of 8 cases. Pediatr Neurosurg. 2008;44:373-75. PMid:18703882 http://dx.doi.org/10.1159/000149903

[62] Konovalov AN, Spallone A, Pitzkhelauri DI. Meningioma of the pineal region: a surgical series of 10 cases. J Neurosurg 1996;85:586-90. PMid:8814160 http://dx.doi.org/10.3171/jns.1996.85.4.0586

[63] Matushita H, Pinto FC, Plese JP. Meningiomas of pineal region in children. Arq Neuropsiquiatr. 2007;65:1000-06. PMid:18094863 http://dx.doi.org/10.1590/S0004-282X2007000600016

[64] Kumar P, Tatke M, Sharma A, Singh D. Histological analysis of lesions of the pineal region: A retrospective study of 12 years. Pathol Res Pract. 2006;202:85-92. PMid:16413691 http://dx.doi.org/10.1016/j.prp.2005.11.006

[65] Lassman AB, Bruce JN, Fetell MR. Metastases to the pineal gland. Neurology. 2006;67:1303-04. PMid:17030775 http://dx.doi.org/10.1212/01.wnl.0000238516.29603.33

[66] Kraker J, Maulucci C, Peng HQ, Reich SG. Pineal metastasis from breast cancer. Arch Neurol. 2009;66:667. PMid:19433670 http://dx.doi.org/10.1001/archneurol.2009.98

[67] Al-Holou WN, Maher CO, Muraszko KM, Garton HJ. The natural history of pineal cysts in children and young adults. J Neurosurg Pediatr. 2010;5:162-66. PMid:20121364 http://dx.doi.org/10.3171/2009.9.PEDS09297 